\title{
Analisis Penyebab Kerusakan Jalan pada Ruas Jl. Ngadirojo - Giriwoyo
}

\author{
Langgeng Satriawan ${ }^{1)}$ \\ 1) Fakultas Teknik, Program Studi Teknik Sipil, Universitas Veteran Bangun Nusantara, Sukoharjo, Jl. \\ Letjen Sudjono Humardhani, No.1, Jombor, Sukoharjo; Telp. 0271-593156. Email: \\ lang.satriawan@gmail.com
}

\begin{abstract}
Abstrak
Penelitian ini dilakukan untuk mengetahui penyebab utama kerusakan pada jalan Ngadirojo - Giriwoyo Km. 44 $+800-\mathrm{Km} .46+800$ dan seberapa parah kerusakan yang ditimbulkan akibat beban yang berlebih (Overload) pada ruas jalan Ngadirojo - Giriwoyo Km. $44+800-$ Km. $46+800$. Penelitian ini menggunakan metode Observasi, yaitu dengan melaksanakan peninjauan langsung dilapangan, dan data yang bersifat sekunder kami analisis menggunakan program komputer, yaitu Microsoft Exel. Berdasarkan hasil survei kerusakan jalan, jenis kerusakan yang terjadi pada ruas jalan Ngadirojo - Giriwoyo Km. $44+800$ - Km. 46 + 800 adalah Lubang, Retak Refleksi, Sungkur, Stripping, Retak kulit buaya, Pengelupasan permukaan, Jumbul. Kerusakan yang dominan pada ruas jalan Ngdirojo - Giriwoyo Km. $44+800-46+800$ adalah Sungkur, Lubang, Retak Refleksi. Dari data LHR yang penulis peroleh, bisa dipastikan penyebab utama kerusakan jalan Ngdirojo - Giriwoyo Km. $44+800-46+800$ dikarenakan oleh kendaraan dengan muatan berlebih (Overload) yang didominasi kendaraan berat atau dalam artian jalan tersebut dipaksakan untuk menerima beban berlebih saat ini. Dari hasil perhitungan pertumbuhan lalulintas (i) dengan metode Eksponensial adalah 7,29\%. Untuk prediksi pertumbuhan lalu lintas ditahun mendatang didapatkan hasil $2019=18,47$ dengan volume 2825,7 (smp/jam), $2024=54,93 \%$ dengan volume 3580,6 (smp/jam) dan $2029=91,38 \%$ dengan volume 4335,5 (smp/jam).
\end{abstract}

Kata kunci: kerusakan jalan, pertumbuhan lalu lintas, overload.

\begin{abstract}
This research was conducted to determine the main cause of damage to the Ngadirojo - Giriwoyo Km. $44+800-$ Km. $46+800$ and how much damage was caused due to overload on Jalan Ngadirojo - Giriwoyo Km. $44+800-$ $\mathrm{Km} .46+800$. This study used the observation method, namely by conducting direct field observations, and we analyzed secondary data using a computer program, namely Microsoft Excel. Based on the results of the road damage survey, the type of damage that occurred on the Ngadirojo - Giriwoyo Km. $44+800-\mathrm{Km} .46+800$ is Hole, Reflection Crack, Sungkur, Stripping, Cracked crocodile skin, Surface peeling, Jumbul. The dominant damage to the Ngdirojo - Giriwoyo Km. $44+800-46+800$ is the Sungkur, Hole, Reflection Crack. From the LHR data that the author has obtained, it can be ascertained that the main cause of damage to the Ngdirojo - Giriwoyo Km road. $44+800-46+800$ is caused by vehicles with overload (Overload) which is dominated by heavy vehicles or in the sense that the road is forced to accept the current excess load. From the calculation of traffic growth (i) using the Exponential method is $7.29 \%$. For the prediction of traffic growth in the coming year, the results obtained are $2019=18.47$ with a volume of 2825.7 ( pcu / hour), $2024=54.93 \%$ with a volume of 3580.6 (pcu / hour) and $2029=91.38 \%$ by volume 4335.5 ( $\mathrm{pcu} /$ hour $)$.
\end{abstract}

Keywords: road damage, traffic growth, overload.

\section{PENDAhULUAN}

Jalan adalah prasarana transportasi darat yang meliputi segala bagian jalan, termasuk bangunan pelengkap dan perlengkapannya yang diperuntukkan bagi lalu lintas, yang berada pada permukaan tanah, di atas permukaan tanah, di bawah permukaan tanah dan atau air, serta di atas permukaan air, kecuali jalan kereta api, jalan lori, dan jalan kabel (Peraturan Pemerintah Nomor 34 Tahun 2006). Prasarana jalan yang terbebani oleh volume lalu lintas yang tinggi dan berulang-ulang akan menyebabkan terjadi penurunan kualitas jalan. Beban lalu lintas adalah beban yang dilimpahkan ke perkerasan jalan melalui kontak roda kendaraan dengan muka jalan terdiri atas berat kendaraan sebagai gaya vertikal, gaya rem kendaraan sebagai gaya horizontal, dan gerakan roda kendaraan sebagai getaran. (Sukirman, 2010). Sebagai indikatornya dapat diketahui dari kondisi permukaan jalan, baik kondisi struktural maupun fungsionalnya yang mengalami kerusakan. Untuk itu, semua prasarana yang terdapat pada suatu sistem 
transportasi khususnya transportasi darat, memerlukan perawatan dan perbaikan kerusakan yang baik. Hal ini dimaksudkan untuk memperpanjang masa pelayanan ekonominya dengan mempertahankan tingkat pelayanan pada batas standar yang aman.

Klasifikasi jalan menurut fungsinya terdiri atas 4 golongan (UU No. 22 Tahun 2009) yaitu jalan arteri, kolektor, lokal, dan lingkungan. Pada umumnya, jalan direncanakan memiliki umur rencana pelayanan tertentu sesuai kebutuhan dan kondisi lalu lintas yang ada, misalnya 10 sampai dengan 20 tahun, dengan harapan bahwa jalan masih tetap dapat melayani lalu lintas dengan tingkat pelayanan pada kondisi yang baik. Untuk mencapai pelayanan pada kondisi yang baik selama umur rencana tersebut, diperlukan adanya upaya pemeliharaan jalan.

Faktor-faktor penyebab kerusakan secara umum adalah peningkatan beban volume lalu lintas, sistem drainase yang tidak baik, sifat material konstruksi perkerasan yang kurang baik, iklim, kondisi tanah yang tidak stabil, perencanaan lapis perkerasan yang sangat tipis, proses pelaksanaan pekerjaan yang kurang sesuai dengan spesifikasi (Udiana, dkk. 2014).

Kabupaten Wonogiri berada di bagian selatan paling timur Jawa Tengah dan berbatasan dengan Jawa Timur bagian selatan seperti Pacitan, Ponorogo dan sekitarnya. Sebagai kota penghubung antar provinsi, sebagian besar masyarakat Wonogiri bekerja dibidang jasa. Ruas jalan Ngadirojo - Giriwoyo diklasifikasikan sebagai jalan kolektor dalam sistem jaringan jalan primer yang menghubungkan ibukota provinsi dengan ibukota kabupaten/ kota dan jalan stategis propinsi. Berdasarkan klasifikasi menurut fungsi jalan, ruas Ngadirojo - Giriwoyo dikategorikan sebagai jalan kelas IIIA, yaitu jalan arteri atau kolektor yang dapat dilalui kendaraan bermotor termasuk muatan dengan ukuran lebar tidak melebihi $2.600 \mathrm{~mm}$, ukuran tinggi tidak melebihi $4.100 \mathrm{~mm}$, ukuran panjang tidak melebihi $21.000 \mathrm{~mm}$ dan muatan sumbu terberat yang diizinkan 8 ton (TPGJAK 1997). Kondisi ruas jalan Ngadirojo - Giriwoyo mengalami kerusakan berupa lubang dan retakan kecil. Kerusakan ini telah diperbaiki dengan cara penambalan (patching) dan pelapisan aspal (overlay). Namun akibat banyaknya kendaraan yang melebihi muatan, maka ruas jalan tersebut saat ini mengalami banyak kerusakan, sehingga tidak lagi nyaman digunakan.

Penelitian ini dilakukan, untuk mengetahui penyebab utama kerusakan jalan pada ruas Ngadirojo - Giriwoyo serta menentukan peningkatan volume kendaraan tiap tahun yang melintas pada ruas Ngadirojo - Giriwoyo.

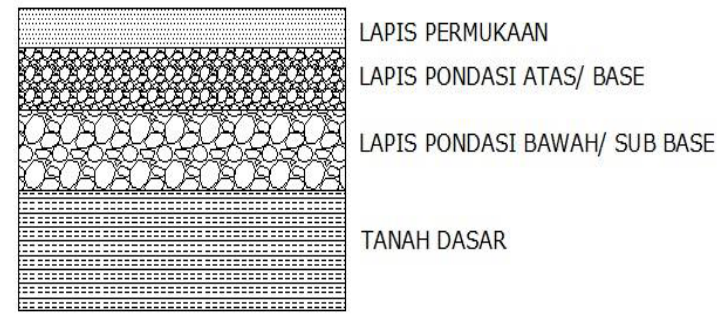

Gambar 1. Susunan Lapis Perkerasan Lentur Sumber : Bina Marga No.03/M/N/B/1983

\section{METODE}

\section{Metode penelitian}

Menurut Dektorat Jendral Bina Marga Tahun 1990 penilaian kondisi perkerasan dengan melakukan survai dilakukan dengan berjalan kaki sepanjang jalan. Hal-hal yang perlu diperhatikan dalam melakukan survei adalah sebagai berikut:

- Kekasaran Permukaan (Surface Texture)

- Lubang-lubang (Pot Holes)

- Tambalan (Patching)

- Retak-retak (Cracking)

- Alur (Ruting)

- Amblas (Depression)

Besarnya nilai prosentase kerusakan diperoleh dari prosentase luas permukaan jalan yang rusak terhadap luas keseluruhan bagian jalan yang ditinjau. Rumus yang digunakan untuk menentukan nilai prosentase kerusakan $(\mathrm{Np})$ adalah sebagai berikut :

$\mathrm{Np}=$ (Luas Jalan Rusak) / (Luas Jalan Keseluruhan) x 100\%

Tabel 1. Nilai Prosentase Kerusakan (Np)

\begin{tabular}{ccc}
\hline Prosentase & Kategori & Nilai \\
\hline$<5 \%$ & Sedikit sekali & 2 \\
\hline $5 \%-20 \%$ & Sedikit & 3 \\
\hline $20-40 \%$ & Sedang & 5 \\
\hline$>40 \%$ & Banyak & 7 \\
\hline \multicolumn{3}{c}{ Sumber : Dinas Bina Marga }
\end{tabular}

3. HASIL DAN PEMBAHASAN 
Ruas Jalan Provinsi Ngadirojo - Giriwoyo merupakan jalan kolektor dengan kelas jalan III dan melayani lalu lintas 2 arah. Survei kondisi jalan dilakukan pada ruas jalan Ngdirojo - Giriwoyo Km. 44+800 - Km. $46+800$ yang terbagi menjadi 4 segmen mempunyai panjang 500 meter. Berikut adalah hasil dari survei kerusakan jalan.

Tabel 2. Kerusakan Lubang Segmen 1 (Ruas Jalan Ngadirojo - Giriwoyo Km. 44+800 - Km. $45+300$ )

\begin{tabular}{ll}
\hline No & \multicolumn{1}{c}{ Kemungkinan penyebabnya } \\
\hline 1 & $\begin{array}{l}\text { Kadar aspal rendah, sehingga film aspal } \\
\text { tipis dan agregatnya mudah terlepas atau } \\
\text { lapis permukaannya tipis. }\end{array}$ \\
\hline 2 & Pelapukan aspal. \\
\hline 3 & Penggunaan agregat kotor. \\
\hline 4 & Suhu pencampuran tidak memenuhi syarat. \\
\hline 5 & Sistem drainase jelek. \\
\hline
\end{tabular}

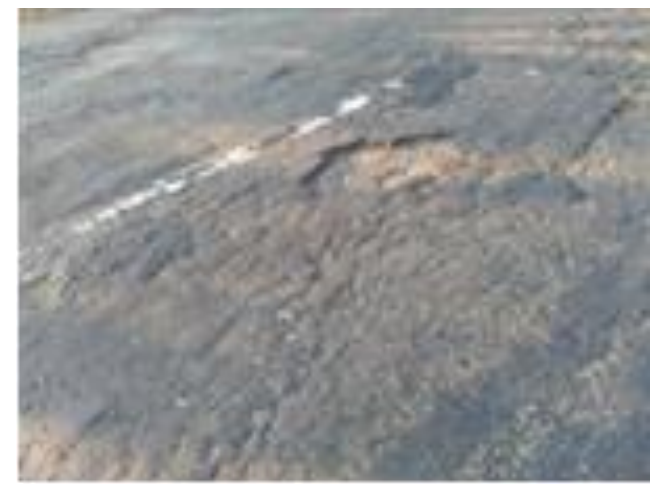

Gambar 1. Kerusakan Lubang Segmen 1

Tabel 3. Kerusakan Sungkur Segmen 2 (Ruas Jalan Ngadirojo - Giriwoyo Km. 45+300 - Km. $45+800)$

\begin{tabular}{cl}
\hline No & \multicolumn{1}{c}{ Kemungkinan penyebabnya } \\
\hline 1 & $\begin{array}{l}\text { Stabilitas tanah dan lapisan perkerasan } \\
\text { yang rendah. }\end{array}$ \\
\hline 2 & $\begin{array}{l}\text { Daya dukung lapis permukaan atau lapis } \\
\text { permukaan atau lapis pondasi yang tidak } \\
\text { memadai. }\end{array}$ \\
\hline 3 & Pemadatan yang kurang saat pelaksanaan. \\
\hline 4 & $\begin{array}{l}\text { Beban kendaraan yang melintasi terlalu } \\
\text { berat. }\end{array}$ \\
\hline 5 & $\begin{array}{l}\text { Lalu lintas dibuka sebelum perkerasan } \\
\text { mantap (untuk perkerasan yang } \\
\text { menggunakan aspal cair). }\end{array}$ \\
\hline
\end{tabular}

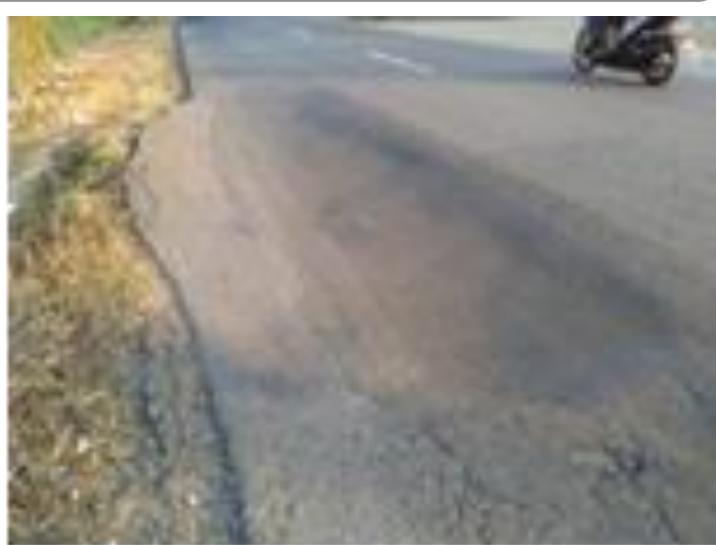

Gambar 2. Kerusakan Sungkur Segmen 2

Tabel 4. Kerusakan Retak Refleksi Segmen 3 (Ruas Jalan Ngadirojo - Giriwoyo Km. 45+800 $-\mathrm{Km} .46+300$ )

\begin{tabular}{cl}
\hline No & \multicolumn{1}{c}{ Kemungkinan penyebabnya } \\
\hline 1 & $\begin{array}{l}\text { Perambatan dari retak susut yang terjadi } \\
\text { pada lapisan perkerasan dibawahnya. }\end{array}$ \\
\hline & $\begin{array}{l}\text { Retak pada lapis perkerasan lama yang } \\
\text { tidak pernah diperbaiki secara benar } \\
\text { sebelum perkerasan tambahan (overlay) } \\
\text { dilakukan. }\end{array}$ \\
\hline 3 & $\begin{array}{l}\text { Perbedaan penurunan dari timbunan } \\
\text { /pemotongan badan jalan dengan struktur } \\
\text { perkerasan. }\end{array}$ \\
\hline 4 & $\begin{array}{l}\text { Perubahan volume pada lapis pondasi dan } \\
\text { tanah dasar. }\end{array}$ \\
\hline 5 & $\begin{array}{l}\text { Adanya akar pohon dibawah lapis } \\
\text { permukaan. }\end{array}$ \\
\hline
\end{tabular}

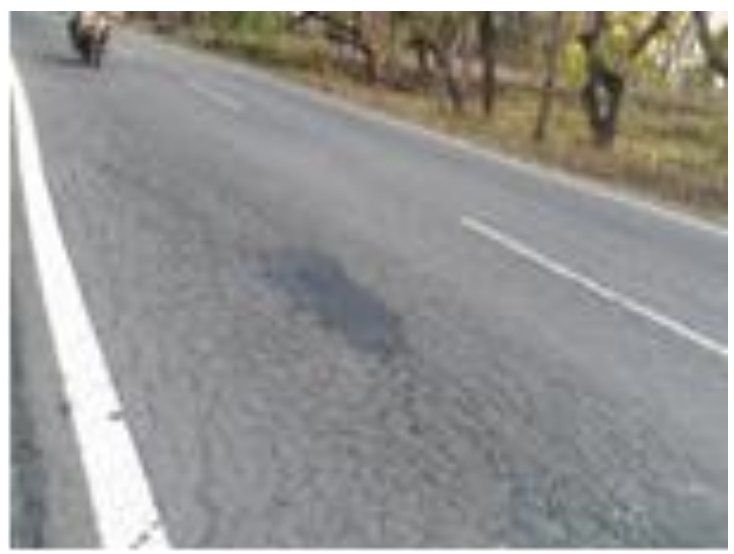

Gambar 3. Kerusakan Retak Refleksi Segmen 3

Tabel 5. Kerusakan Sungkur Segmen 4 (Ruas Jalan Ngadirojo - Giriwoyo Km. 46+300 - Km. $46+800$ ) 


\begin{tabular}{cl}
\hline No & \multicolumn{1}{c}{ Kemungkinan penyebabnya } \\
\hline 1 & $\begin{array}{l}\text { Stabilitas tanah dan lapisan perkerasan } \\
\text { yang rendah. }\end{array}$ \\
\hline 2 & $\begin{array}{l}\text { Daya dukung lapis permukaan atau lapis } \\
\text { permukaan atau lapis pondasi yang tidak } \\
\text { memadai. }\end{array}$ \\
\hline 3 & Pemadatan yang kurang saat pelaksanaan. \\
\hline 4 & $\begin{array}{l}\text { Beban kendaraan yang melintasi terlalu } \\
\text { berat. }\end{array}$ \\
\hline 5 & $\begin{array}{l}\text { Lalu lintas dibuka sebelum perkerasan } \\
\text { mantap (untuk perkerasan yang } \\
\text { menggunakan aspal cair). }\end{array}$ \\
\hline
\end{tabular}

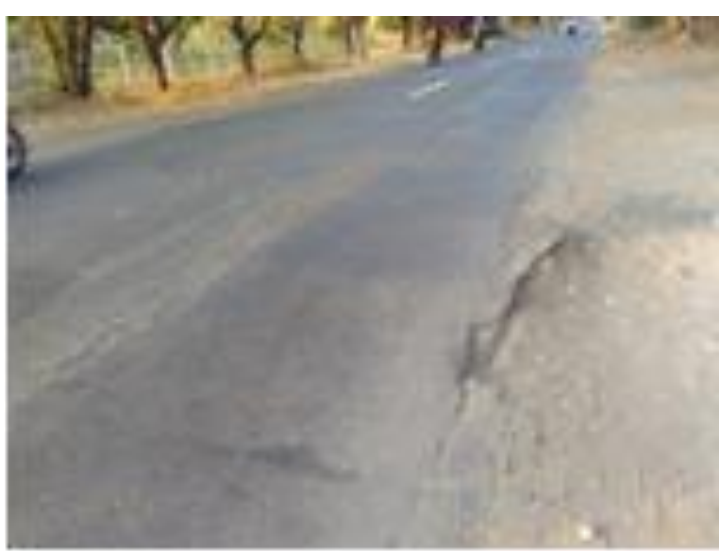

Gambar 4. Kerusakan Sungkur Segmen 4

Berdasarkan tabel diatas dapat diketahui bahwa dari keempat segmen tersebut kerusakan paling dominan adalah lubang, retak blok dan sungkur. Bisa dikatakan bahwa disepanjang jalan Ngadirojo - Giriwoyo Km. 44+800 - Km. 46+800 mengalami kerusakan jalan, antara lain lubang, sungkur, retak blok dan apabila kerusakan tersebut tidak segera diperbaiki, maka akan membahayakan bagi pengguna jalan tersebut.

\section{Penilaian Tingkat Kerusakan Jalan}

Dengan melihat data prosentase kerusakan maka Ruas Jalan Ngadirojo - Giriwoyo Km. 44 $+800-$ Km. $46+800$ bisa dipastikan jalan tersebut mengalami kerusakan pada tingkat ringan karena pada prosentase kerusakan ratarata sebesar 9,43\% mengalami kerusakan yang sedikit sekali.

\section{Pertumbuhan Lalu Lintas}

Dari hasil perhitungan dengan metode Eksponensial didapat angka pertumbuhan (i) sebesar $10,94 \%$.

Dari analisa data di atas untuk prediksi pertumbuhan lalu lintas di tahun mendatang yaitu tahun 2019, 2024 dan 2029 seperti pada tabel dibawah ini.

Tabel 4.15 Angka prediksi pertumbuhan lalu lintas pada jalan Ngadirojo - Giriwoyo Km. $44+800-$ Km. 46+800

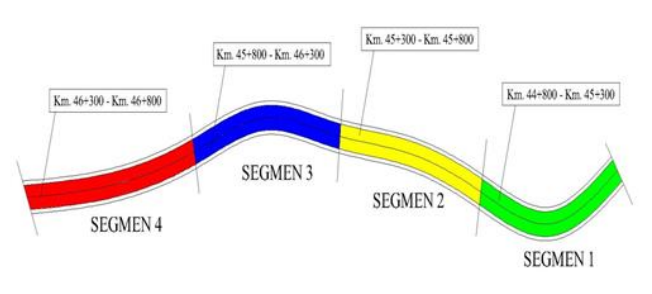

Gambar 5. Tipikal Jalan Ngadirojo - Giriwoyo

\section{KESIMPULAN}

Berdasarkan hasil analisis dan pembahasan dapat diambil beberapa kesimpulan yaitu volume lalu lintas di Ruas Jalan Ngadirojo Giriwoyo Km. $44+800-46+800$ dari 3 tahun terakhir, yaitu dari tahun 2016, 2017, 2018 rata -rata mengalami kenaikan sebesar (10,94\%). Berdasarkan hasil survei kerusakan jalan, jenis kerusakan dan tingkat kerusakan yang terjadi pada Ruas Jalan Ngadirojo - Giriwoyo Km. 44 $+800-46+800$ adalah lubang, retak refleksi, sungkur, stripping, retak kulit buaya, pengelupasan permukaan, jumbul. kerusakan yang dominan adalah sungkur, lubang, retak refleksi. Prosentase kerusakan maka Ruas Jalan Ngadirojo - Giriwoyo Km. $44+800$ - Km. 46 +800 bisa dipastikan jalan tersebut mengalami kerusakan pada tingkat ringan karena pada prosentase kerusakan rata - rata sebesar 9,43\% mengalami kerusakan yang sedikit sekali

Dengan melihat data LHR yang penulis peroleh, bisa dipastikan penyebab utama kerusakan jalan Ngdirojo - Giriwoyo Km. 44 $+800-46+800$ adalah dikarenakan oleh kendaraan dengan muatan berlebih (Overload) yang didominasi kendaraan berat atau dalam artian jalan tersebut dipaksaan untuk menerima beban berlebih saat ini.capan terima kasih terutama ditujukan kepada pemberi dana penelitian atau donatur. Ucapan terima kasih dapat juga disampaikan kepada pihak-pihak yang membantu pelaksanaan penelitian 


\section{DAFTAR PUSTAKA}

Bina Marga. 1983. Manual Pemeliharaan Jalan No.03/M/N/B/1983. Jakarta

Presiden Republik Indonesia. 2006. Peraturan Pemerintah Republik Indonesia. Nomor 34 tahun 2006 Tentang. Jalan. Jakarta

Presiden Republik Indonesia. 2009. Peraturan Pemerintah Republik Indonesia. Nomor 34 tahun 2006 Tentang Lalu Lintas Dan Angkutan Jalan. Jakarta

Sudiyono, Dkk. 2014. Analisis Kerusakan Dini (Premature Failure) Ruas Jalan Nguter Wonogiri. Jurnal Teknik Sipil Magister
Teknik Sipil Universitas Sebelas Maret, Vol. II. No. 1 Maret 2014 ISSN : 2339-0271.

Sukirman Silvia, 2010, Perencanaan Tebal Struktur Perkerasan Lentur, Penerbit Nova, Bandung.

Udiana, I. Dkk. 2014. Analisa Faktor Penyebab Kerusakan Jalan (Studi Kasus Ruas Jalan W. J. Lalamentik Dan Ruas Jalan Gor Flobamora). Jurnal Teknik Sipil Vol. III, No. 1, April 2014.

Wibowo, A. 2016. Analisa Penyebab Kerusakan Jalan Pada Jalan Lingkar Selatan Sragen. Skripsi : Univet Bantara Sukoharjo. 